\title{
Crime by the Commons, Emerging Trend in Social Media
}

\author{
Swati Arjun ${ }^{1}$ and Shikha Rai ${ }^{2}$
}

\begin{abstract}
This research article presents a study on CRIMES that are done on social media platforms, while engaging in discussions, sharing information, giving opinions and posting an update. Since, the study focused on online crimes such as social bullying, social lashing, social media trolling and conducting a media trial leading to social media lynching. The study was done while taking up a pluralist approach, when the research took up four case studies and more than half a dozen of secondary sources. Besides, the victims the researcher made it a point to take opinions from leading Psychiatrist, political scientist, anthropologists and cyber expert, before coming into any conclusion. All this was done in the best possible scientific manner to come into a logical conclusion. Special care was taken while selecting samples for the study, so that maximum representation could be ensured. Special care has been taken to investigate the case of suicide to ascertain the reason behind the incident, if it was a case of failed self-presentation; Leading to a logical and empirical study.
\end{abstract}

Keywords: Crime, Social Media, Cyber Crime.

\section{Introduction}

Society is the premise, based on which civilizations have been formed from ages, and democracy is the concept which has always been a key factor governing the idea of a liberal and progressive society. The word 'Social' has been derived from the Latin word 'socii', which means "allies". However, it is used in many different senses and regarded as a concept. Anything that does not fall in favour of an established society is called 'Anti-Social'; Terms like Social realism, Social justice, Social psychology and Social capital implies a kind of Social process- which involves the society or which revolves around the periphery of the Society.

Today, the human society has progressed towards a digital age. Being digitally able has become the need of every person, in order to survive, compete and excel in their chosen field, in their community and in their society. But, the fact is that it does not matter that whether we live in stone age or digital age, flow of information has always been the need of the society- be it a democracy or an authoritative regime.

Thus, social media platforms are 'COMPUTER MEDIATED' virtual / digital communities which facilitates the creation and sharing of various information in textual, picture, animation and video form. For example- Face book and Twitter. There is no set rule to qualify as a provider or consumer of information in these platforms,

1 Ph.D. Research Scholar

2 Assistant, Professor, School of Journalism and New Media Studies, Indira Gandhi National

Open University, New Delhi-110068 therefore everyone who is present over there is both an informer and consumer of news. This has led to originate a new term in this context which is called, 'PRO-SUMERS'. Which means Provider + Consumer.

Having discussed the importance of society, we can't ignore the concept of crime, punishment, murder, bully, trial, offence etc. This too had been as old as origin of Society, therefore...paving way to construct laws. But from time immemorial there had been instances where common people have taken the onus on themselves to punish, demean, boycott or bully the culprit on their own, then taking a lawful route. When a group of people or a mob in kills someone for an alleged offence without a legal trial then it's called a lynch or lynching. It is an extrajudicial punishment, often characterized by informal public executions. It can also be called an extreme form of informal social group control, to either punish an alleged transgressor or even to intimidate a group.

The first instances of mob lynching were found in societies which existed long before European settlement of North America. The incidents often bore in itself the element of racism. History of lynching in India also dates back to pre-freedom era, especially during partition of India and Pakistan. Post-independence also there had been occasional instances of the same nature, under the garb of religious and communal differences. But, the trend took a sudden rise after 2010. According to a research report published in Indiaspend.com, From the year 2010, 86\% victims of mob lynching cases were Muslims, and $97 \%$ of these incidents took place after 2014. 
Trolling by the virtual society in social media platform has its root grounded in the same mindset. It is an emerging trend where common people are getting involved in organized virtual crime against a person who could be a minority in literal terms or who could have a marginalized mass-base.

\section{Method of crime}

Both Facebook and Twitter are Two-way interactive media platforms where the users are free to comment, like, dislike, share, react and even lash out at each other. This tool of freedom of expression has culminated into some specific behaviour pattern of the users. On the basis of aggression, language, intimidation level and degree of harm caused to the other person, this process could be broken into 3-4 categories, namely- cyber bullying, trolling, lashing and finally culminating into social media trial.

Those who fall prey to this trend are people from all background. Celebrities, (Katrina Kaif and Sunny Leone) popular personalities (Ravish Kumar \& Barkha Dutt), activists, feminists (Kavita Krishnan, Gurmehar Kaur), journalists (Rana Ayub, Neha Dixit) and common man. (Khursheed Anwar).

The onslaught of such crime against these people has often resulted into them quitting social media, deactivating their account, becoming passive, slipping into depression and at times even committing suicide. There have been instances when certain people have been first attacked and threatened in first social media, then murdered. like-Gauri Lankesh, the Bengaluru based Vernacular journalist who was first threatened on Facebook, then murdered for her antiestablishment views, and even after death was subjected to social media lynching. Where people were abusing her by calling names like (Qaumi \& Bitch) and resorting to slut shaming.

\section{Significance}

According to social media experts $90 \%$ of social media engagements are negative. There is no fixed norm to these crimes over here. It could start from hysterical reaction to an unpopular opinion, to public shaming of individuals for their appearance, sexual preference or political beliefs. This is often done to abuse others or force them to conform to their own or socially more accepted views. Such backlash can be emotionally, mentally and psychologically more brutal and incredibly damaging. As it affects our reputation, friendships, relations and even career which amounts to our social capital. This curtails free speech, exchange of ideas and difficult discussions on virtual platform. A sense of fear prevails, people are divided into various groups and communities. Which according to leading (Psychologists-Social anthropologists) is major cause of Mental illness. There had been cases of social media trial resulting into suicide too. (Khurshid Anwar and Malini Murmu). Social media fuelled vigilantism has also resulted into actual lynching of nine people in Jharkhand on suspicion of child lifting.

\section{Objective}

The aim and objective of this study is to primarily investigate the concept of online trolling, bullying, abuse and rampant social media trial to punish an alleged offender. Can it be equated with a real physical incident of mob lynching. Also, Even after repetitive lashing why do people still want to be on social media platform; Are the victims aware of their social media rights and cyber laws; Has Freedom of expression, the basic constitutional right is being misused here; What are the characteristics of such people who either become a part or mute spectator of such crime.

\section{Review of literature}

S. Kumar wrote in the Huffington Post that Social media lynching is a dark reminder of our past. (Dark Ages 2.0: The Return of Public Lynching. July 14, 2016.) In this article Kumar stated that, the only thing that's changed is the medium. The rise of online technology and social media in particular, has created a new brand of public lynching, which is thankfully limited to a virtual universe but still no less harmful. Kumar further wrote that, 'What makes this phenomenon even more disturbing is that it doesn't really depend on merit but solely on the collective opinion of a group, which then becomes the gospel truth.'

In a story published in FirstPost.com (Mob lynching a political tool to divide and rule, June 29th 2017) while talking to this researcher, Social psychologist and anthropologist Ashish Nandi said that, 'there is a stark similarity between an incident of mob lynching and social media trial. Those who do the crime are normally faceless people, not happy with their lives, frustrated and dejected. Unaware of the same...they choose an impromptu target and start attacking them.

In the same article Senior Psychiatrist at Fortis Hospital Dr. Manu Tiwari said, 'The psychology of the mob is either constructive or destructive. However, it serves the purpose of a tool or platform where our personal grievances are shaped into collective grudge. There the 
individual is disguised as a mob- which helps him/her to cross the personal boundary line.

In a story published on a leading English website The Quint on 11 April, 2016 titled (Don't Let Social Media Lynching Be the Next Big Thing in 2016) the author wrote that- 'India breeds cynicism in one form or the other and Social media has been the modern day catalyst, may it be Twitter or Facebook.' He gave the example of a journalist and his organisation being trolled for sharing a photo-shopped image of PM Modi by his twitter handle.

Journalist Author Tavleen Singh, too addressed the same issue in one of her articles published in The Indian Express on May 14 ${ }^{\text {th }}, 2017$. Titled as 'A media lynching', Singh took up the case of Republic TV and its editor Arnab Goswami. According to Tavleen, 'While investigating the death story of Sunanda Pushkar wife of Cong MP Shashi Tharoor, the channel decided that Sunanda Pushkar was murdered and that her husband was complicit. In this 'scoop' Tharoor was judged and sentenced on national television with a followed accusations and hate speech in Social Media. (An example of media trial in the garb of investigative journalism.)

On March 5th 2015 in Dimapur, an enraged lynch mob mercilessly butchered Syed Sarif Uddin Khan, by breaking the central prison. Khan was ruthlessly killed after being beaten him with sticks and dragged naked through-out the town. All this while the police did not tried to either prevent or check the mob. Khan was jailed in a case of rape. But details suggested that the social media was used to whip up sentiment by describing Khan as Bangladeshi rapist in an online campaign on social media. It was later established that Social Media Campaign Preceded Lynching in Nagaland and Police were Silent Spectators to the Crime.

Fortune Nwaiwu, Principal Consultant at Africamonitor.info at Linked in wrote in his article dated May 13 th $^{\text {th }} 2017$ titled, 'Going Viral: cyber lynching, e-mobs and the emerging menace of social media jungle justice', In the righteous world of those involved in mob lynching or jungle justice, facts don't matter. All that is required by the mob to jump into action is an accuser and an accused. The mob becomes the judge, jury and executioner, dispatching the accused without an iota of empathy for their fellow human.'

In the research article 'Deliberation or Self Presentation? Young People, Politics and Social Media,' published in Nordicom Review 35 (2014) Author Tanja Storsul argues that how politically engaged young people use social media for political purposes. He further explains that how social media integrate different forms of communication and collapses social context.

Author Pradeep Nair in his research article titled, 'Democracy in Digital age : Revisiting the Gandhian Idea of Civic Engagement', published in Mainstream Weekly, VOL LV No 41 , discusses that the digital media not only accelerates the access to information but also develops new attitude for negotiations with the socio-cultural surroundings.

\section{Theoretical framework}

Based on the above research studies, the theoretical framework that the researcher feels apt for her proposed research is Spiral of Silence and Theory of Public Sphere given by Haber Mass. Originally proposed by German political scientist Elisabeth Noelle- Neumann, theory of Spiral of Silence, refers to the tendency of the people to remain silent in situations where they feel that their individual view is of no significance or opposite to the majority view on a subject. The theory posits them to remain silent, for mainly two reasons: first- fear of isolation in practical and physical terms; and second, fear of reprisal or more extreme isolation like loss of job or status or position. Media too has an important role in this process, especially in dictating or perpetually dictating the opinion.

The second theory which seems to be in action over here is The Public Sphere theory given by HaberMas. In this theory Habermas has discussed public sphere as that area in social life, where individuals can come together and freely discuss issues related to social and political action or concern. The main feature of this theory is the equal chance given to each person to start a conversation, ask question, discuss, examine and propose. Which is quite close to the functionality of social media?

\section{Research Design/Methodology}

The methodology that the researcher pursued during this study was adhering to the pluralist approach of gathering data both from primary and secondary sources. She started with gathering information pertaining Incidents of social media trial and social media abuse. Finding out the time graph of these incidents; like-when, why and how it started. Identifying external or foreign factors which led to the rise of such incidents; Review of previous studies on topics related to this trend. Subsidiary ideas and keywords; Collecting first-hand account through case studies of some cases which happened in the 
recent months and years, citing factors which made them relevant for this study and finally taking opinions of Anthropologists, Social Scientists, Psychiatrists and Cyber expert.

The justification for taking this study in a pluralist way was to make it more scientific, empirical, relevant and contemporary. Since, the focus of the study is to decipher the trend in social media, thus- there was no better way to include experiences of those who were affected by it.

\section{Data Collection}

The stages of data collection were divided into two parts: Primary and Secondary. I started out with my first section while approaching to people who had experienced online trolling or online crime of any degree. My first case was of Prof. Anand Pradhan, who is a leading academician residing in Delhi. Three years ago Dr. Pradhan was subjected to virile accusations and abuse on Facebook, after former member of his family and a leading politician from opposition came together as a couple. Both Pradhan and his former family member were slut-shamed, trolled and abused on social media, forcing Pradhan to completely withdraw from this Platform. While sharing his views, Dr. Pradhan said opined that both virtual and real world are integral to each other. He said, 'Look at the language used in TV channels, the ones used by politicians on national TV, Slangs used in TV Shows, Films, in feudal setups, Diktat by Khap-Panchayats, Incidences of Honor Crime; are they not more dangerous than online trolling or online abuse meted out to peoples.' The incident did disturbed him in more than one ways, but he also says that- such incidents of aggression are on a rise because of the challenge that is meted out to them through more and more liberal souls around.' He added, 'Though, the incident was hazardous, but still I managed to pull out of it, because of my willpower and strength and secondly by the positive support of family and friends, it gives a lot of strength.'

The second case study for this article was that of Ran aAyub, a well-known journalist living in Mumbai. Rana was not only slut shamed but even threatened of rape, murder and possible assault to her family members by the Online Trolls. All this for stories on riots in Gujarat, the antiestablishment views and her strong Anti-right political opinions. While sharing her experience with this researcher, Rana shared the nuances and modus-operandi of these trolls and her observation regarding the same. When asked If virtual trolling or lynching is as life threatening as actual mob lynching;
She replied- I don't think. Having said that threats online cannot be taken lightly. There is precedence to virtual threat leading to a murder. Gauri Lankesh was threatened every day. Her murder gave a reality check to many of us. When asked about the impact of such incidents on emotional and psychological level she said- On days when an army of trolls attacks you it takes a toll on you. When i defended Gurmehar Kaur on social media, they got an entire state sponsored machinery behind me. I almost wanted to quit social media. The photoshopped images, the abuse, the threats to rape. They take a major toll on your mental health. According to Rana, it also affected social and professional life. She said, 'When a lie is repeated a thousand times you wonder if people who are also your friends will accept it as the truth. You go into a shell.' When asked about the timeline of such incidents, she categorized it to her tenure with Tehelka in the year 2 010, when Amit Shah was sent behind bars because of her story. Continuing till date. Finally, the researcher asked her if all this experience has made her more cautious and alert on subconscious level or has she confined her boundaries to keep for safety? To this she replied by saying, 'No I have not. Truth be told. But yes i do not engage with trolls anymore. i do not reason with them anymore.'

My third sample or case study was that of a young college girl Gurmehar Kaur. Barely, 22 years old Gurmehar was quite a vigilante student of her college named Ramjas. Last year during a concert in her college, there was fight between two different groups student bodies in the college where she raised her voice against ABVP, the student wing of the reigning saffron party of India. Gurmehar feels that all this started after 2014- when the new government was formed in Delhi. She also feels that when such incident started happening it was not condemned by celebrities or people of importance, thus making others believe that it was all normal. When she went through this hounding and abuse, she left Delhi and joined her family in Punjab. She was in a depressive state, could not eat for days and even sleep, was unable to even speak. Then she had gone for a ten day Vipassana course, which helped her coming out of it. Initially scared for her life and social capital, she eventually came over it with the help of her family, friends, teachers in college and supporters. But, this has changed her way of life. Now, she doesn't travel on public transport, it's a bit difficult for her to trust people, don't go to movie or market alone. She takes precaution while venturing out, hides her face with dupatta, don't let people know 
about her whereabouts. According to her this whole experience will never go away from her psyche. She concludes by saying that mob lynching kills a person, compared to that online trolling doesn't harm you physically but it leaves a lifelong scar, too difficult to erase.

In the year 2015, Khursheed Anwar, an academic intellectual and advocate of feminist rights was levelled with accusations of rape. Khursheed was also the director of an NGO called Centre for Social Democracy. After the accusations went viral on Facebook, he demanded that a legal FIR should be filed against him, and the case should go to court. But no one paid heed to his requests or what he was saying, a social media trial started taking place against him. Unable to face the pressure and social lynching, Anwar committed suicide by jumping from the $9^{\text {th }}$ floor of his apartment. While, digging the incident, the researcher talked to Prof. Purushottam Agarwal and his wife, who were very closely related to Khursheed and with whom Khursheed had, had the last conversation about the incident. According to Prof. Agarwal, while talking to him Mr. Anwar showed no sign of anxiety, instead he talked of fighting back. But, his anticipation is that he took this drastic step on a weak moment, thinking about the drastic repercussions of this scandalous affair. Dr. Agarwal also highlights the fact- that since had a very active social life, where he wrote extensively about literature, society and man-woman relationship. He had many female admirers on social media and all this affected him a lot. The incident was a threat to his social reputation, which he thought he would never be able to regain. He had created an image of himself in social media which was very progressive, intellectual and some sort of celebrity status. The potential loss of that status and absence of supportive family and friends drove him to kill his own self.

The second stage of data collection was of cases where people both common and distinguished fall prey to online trolls. This included journalists like Ravish Kumar and BarkhaDutt, for their anti BJP stance,

https://www.dailyo.in/variety/trolls-ravishkumar-modi-open-letter-death-threats-twitterwhatapp/story/1/19791.html

http://www.hindustantimes.com/indianews/let-s-talk-about-trolls-trolling-is-a-weaponto-silence-women-barkha-dutt/storyA9X3fAuRwZiwVrhYQnKbYL.html

Trolling Sunny Leone for adopting a girl child, because she had been a porn star herselfhttp://www.thenewsminute.com/article/trolls- sunny-leone-s-photo-adopted-child-show-exactlyhow-prejudiced-we-are-65722

Slut shaming and brutally trolling DeepikaPadukone for her new movie Padmavati, a maxim photoshoot or being too skinnyhttp://www.republicworld.com/s/12468/deepi ka-padukone-brutally-trolled-for-sharing-a-poston-padmavati

Trolling ShashiTharoor for his comment on Ms. World ManushiChhillarhttps:/ / www.google.co.in/url?sa=t\&rct=j\&q=\&e src $=$ s\&source $=$ web\&cd $=11 \& c a d=$ rja \&uact $=8 \& v e d$ $=0 \mathrm{ahUKEwjZxoyFgvvXAhUKWrwKHdLjCzoQt}$ wIIWTAK\&url=https $\% 3 \mathrm{~A} \% 2 \mathrm{~F} \% 2 \mathrm{Fwww}$.youtube. com $\% 2$ Fwatch $\% 3 \mathrm{Fv} \% 3$ DvdOZ7jd0FZw\&usg=AO vVaw1JM33z9mYqhLYo__84s5HO

Slut shaming Pakistani Actress Mahira Khan for wearing a short dress and smoking cigarettehttps://www.google.co.in/url?sa=t\&rct=j\&q=\&e src $=$ s\&source $=$ web\&cd $=13 \& c a d=$ rja\&uact $=8 \& v e d$ $=0$ ahUKEwjjy_Cfg_vXAhWKgLwKHUCbDz4QF ghmMAw\&url=http \%3A\%2F\%2Fwww.india.com $\% 2$ Fshowbiz\%2Franbir-kapoor-and-mahira-khanhang-out-together-actress-gets-trolled-for-herdress-and-smoking-check-tweets2489669\%2F\&usg=AOvVaw02VSa5aKgDYnJwvb 0kAx_W

Activist Harsh Mander targeted for taking up issues of Gujarat riots. https://scroll.in/article/851908/researchinglives-on-the-edge-why-harsh-mander-believesthe-tax-notice-to-his-think-tank-is-unfair

In her research paper, 'Digital hatred, real violence: Majoritarian radicalisation and social media in India,' author and journalist Maya Mirchandani argues that Social Media is playing a huge role in the ways people are communicating with each other and disseminating information amongst each other.' (Maya, August 2018).

And this is just not a trend specific to India, but many parts of world which have a democratic setup, there the divide between 'Us against Them', has gained prominence in the last few years. The standard way to create a divide between two different sets of people or group, or person vis-àvis a group is done through igniting or giving a trigger to the sentiments of people at large. This sentiment is largely attributed to one's religion, caste, eating and dressing habit, faith, culture etc. Anyone, who is offended by someone else, tries to exaggerate and amplify his feeling of hurt and anger on Social Media by the use of digital technology which do not have any boundaries as of now (George, 2016). Cherian George emphasizes that the main objective of hate speech 
is achieved when a divisive narrative is created and people are mobilized around a particular agenda.

The list is endless and occurrences more than often. Despite from being different backgrounds, all those who fall prey to online trolls have some area of disagreement between them. It could be different political ideologies, life style, religion, community, social strata or even color of the skin. One can mere think of any diversity factor, and there could be an easy passage for online abuse.

\section{Analysis/Discussion}

The researcher went ahead with this research with few objectives in mind. First of which was to investigate the concept and trend of online trolling, bullying, abuse and rampant social media trial as a practice and if it can be equated with an incident of physical mob-lynching. During the course of study and specially data collection, this was clearly evident that though the offence of online crime, in the form of abuse, trolling, lashing and trial was not less harmful than being actually killed or targeted or cornered...it was by and large established that both these acts were not similar in nature. There was the difference in degree of their intensity. In a real mob-lynching incident the victim has no scope to run away, but in virtual world one can easily log-off and move ahead. Shail Mayaram an anthropologist at CSDS, explains the difference between the two as physical and non-physical offence. Compared to crowd lynching which is a criminal offence, online lynching or trolling falls into a grey area. However, because of this only it is more harmful also- as the perpetrator is a faceless-nameless identity, who can't be prosecuted. It results into a kind of isolation, victims are forced to go into their shell, can slip into depression but if one is mentally strong and surrounded with considerate friends then they can easily come out of it, as happened in the case of Anand Pradhan and Gurmehar kaur. Someone like Shashi Tharoor just need a tweet to demolish the morale of the whole troll army, or someone like Rana Ayub can just choose not to engage with trolls.

The second objective of this study was to find out that even after repetitive lashing why do people still want to be on social media platform; the answer to this could not be in black and white. We need to understand that in today's world if we are in public sphere then one must be prepared to face such cornered incidents time and again. The world is going digital, and one can't survive socially and professionally by just being absent on social media. As Psychiatrist Dr. Manu
Tiwari says, it's an occupational need which can't be neglected. The third objective of the study was to find out- If the victims of online abuse are aware of their social media rights and cyber laws; Cyber Expert Pawan Duggal says that in India we do not have Charter of Internet rights. What we have is just Information and Technology Act2000. Besides this, we don't have any precise rights. Article-21 of the constitution gives the fundamental right to life. In August 2017- Right to privacy was passed which also meant Right to Access to Internet. Which in turn ensures Right to have a dignified life.(Specific for Netizens and internet users.) Duggal emphasizes on the need to disconnect and even regulate our lives in relation to social media. Care and Caution were his gospel suggestion.

The last of the four objectives has been to find out if freedom of expression, the basic constitutional right is being misused in social media platforms, and what are the characteristics of such people who either become a part or mute spectator of such crime. In the absence of stringent preventive laws for online crime, it would not be right to state social media platforms are misusing the right to freedom of expression. The degree of harm depends directly on the fact that, how much sensitive the victim is to online abuse or online criticism. To survive in such situations, one needs to desensitize himself from verbal and textual public abuse to survive and excel. Self-control and self-regulationare the keyword.

\section{Conclusion}

The Present Study of Crime by the commons, emerging trend in social media, shows that with the penetration of internet and internet based new media into our daily lives, how crime too has expanded its horizon and penetrated deep into our psyche with the help of virtual tools. After examining the data collected, through both primary and secondary sources the researcher has come to the conclusion that, despite of being capable of harming a human existence in the most saddest ways, virtual trolling, abuse, bullying and social media trial can't be equated with the concept of mob-lynching as of now. This is mainly because of the physical and non-physical aspect of harm that both of them possess respectively. However, there had been one or two aberrations like of Khurshid Anwar and a young student on Bengaluru called Malini Murmu, where the victims lost their life to the pressure build by Social Media Trial. But after having firsthand account of experiences of people who faced such outpour, examples from secondary sources and taking expert opinions of Anthropologists, Psychiatrist and Cyber Expert, it can be assumed 
that the outcome or the degree of individual loss of any victim is directly related to his/her mental and emotional strength. (Ex: Shashi Tharoo and Mahira Khan).

As Psychiatrist Dr. Manu Tiwari pointed out that anyone who tries to bully someone is not a normal person. He is insecure with low selfesteem and low self-respect; and his insecurity is manifested through his aggression. This must first and foremost deal at individual level then family and finally social level. Because, more the frequency of such incidents bigger is the loss of humans. On an individual level there is a loss of confidence in the person, on family level of mutual trust and on the level of society there is a huge loss of moral, ethical and human values.

At the end of the day it's the mental strength, immediate surroundings, friends and families who play a major role in tackling the whole situation. Despite some alarming situation and symptoms, if tackled in an efficient manner, the magnitude of the harm caused by such attacks could be easily mineralised or even discarded.

\section{References}

Storsul, T. (2014).Deliberaion or Self presentation. Nordicom review 35, 17-28. Retrieved December 9, 2017

P. N. (september 30, 2017). Democracy in Digital Age.Mainstream, VOL LV No 41. Retrieved December 9, 2017
S. (. july 14, 2016.). The Return of Public Lynching. Huffington Post .Retrieved December 9, 2017.

S. A. (june 29th 2017). Mob lynching a political tool to divide and rule,. Firstpost.com. Retrieved December 9, 2017.

F. N. (may 2017). Going Viral: cyber lynching, e-mobs and the emerging menace of social media jungle justice'. Africamonitor.info .Retrieved December 9, 2017.

Don't Let Social Media Lynching Be the Next Big Thing in 2016. (april 2016). The quint.Retrieved December 9, 2017.

T. S. (may 2017). 'A media lynching',. The indian express. Retrieved December 9, 2017.

P. N. (september 30, 2017). Democracy in Digital Age.Mainstream, VOL LV No 41. Retrieved December 9, 2017

Storsul, T. (2014).Deliberation or Self presentation.Nordicom review 35, 17-28. Retrieved December 9, 2017.

https://www.orfonline.org/research/43665digital-hatred-real-violence-majoritarianradicalisation-and-social-media-in-india/

George, Cherian, Hate Spin: The Manufacture of Religious Offense and Its Threat to Democracy. MIT Press, 2016. 